\title{
BURSECTOMY IN GASTRIC CANCER SURGERY: A META-ANALYSIS
}

\author{
YANGJUN LI ${ }^{1 *}$, YUJIE LI ${ }^{1}$ AND KANGHAI WANG ${ }^{2}$ \\ ${ }^{1}$ Department of Surgical Oncology, Ningbo No. 2 Hospital; ${ }^{2}$ Department of Surgical Oncology, Ninghai County \\ Hospital of Traditional Chinese Medicine, Ningbo, China
}

\begin{abstract}
Background: Bursectomy consists of surgically removing the peritoneal lining covering the pancreas and the anterior plane of the transverse mesocolon during gastrectomy. However, there are little data to indicate whether bursectomy has a clinical benefit. Objective: The objective of this study was to study the effect of bursectomy on complications, recurrence, and overall survival of patients with gastric cancer. Methods: The publicly available literature published from January 2000 to July 2017 concerning gastrectomy with bursectomy and standard gastrectomy for gastric cancer was retrieved by searching the national and international online databases. Meta-analysis was performed after the data extraction process. Results: Eight studies were finally included for a total of 1644 patients, of whom 644 underwent bursectomy and 1000 received standard gastrectomy without bursectomy. As shown by the meta-analysis results, there were no statistically significant differences in the presence of total post-operative complications (odds ratio $[\mathrm{OR}]=1.06,95 \%$ confidence interval $[\mathrm{Cl}][0.83-1.35], p=0.63$ ), overall recurrence $(\mathrm{OR}=1.07,95 \% \mathrm{Cl}[0.77-1.50], p=0.68)$, 3-year overall survival $(\mathrm{OR}=1.30,95 \% \mathrm{Cl}[0.82-2.07], p=0.26)$, and 5 -year overall survival ( $\mathrm{OR}=0.91,95 \% \mathrm{Cl}[0.66-1.27], p=0.58)$. Conclusion: Although application of bursectomy in radical gastrectomy did not increase post-operative complications, it offered no benefit to control tumor recurrence or improve overall survival. (REV INVEST CLIN. 2019;71:98-105)
\end{abstract}

Key words: Bursectomy. Complications. Recurrence. Overall survival. Gastric cancer. Meta-analysis.

\section{INTRODUCTION}

Bursectomy is defined as the removal of the peritoneal lining covering the pancreas and the anterior plane of the transverse mesocolon during gastrectomy. The rationale for en bloc resection of the postgastric cavity includes the presence of free cancer cells, retrogastric lymphatic vessels, and micrometastases $^{1}$. Moreover, bursectomy removes some retrogastric lymphatic vessels. This procedure is recommended in the Japanese gastric cancer treatment guidelines as part of the radical surgery for gastric cancer to remove micrometastases disseminated into the bursa omentalis ${ }^{2}$.

On the other hand, there are questions arising from the anatomy, as the bursa omentalis is not actually a closed cavity, being connected to the free abdominal cavity through the foramen of Winslow. Moreover, a bursectomy causes some surgical stress when

\section{Corresponding author:}

*Yujie Li

Northwest Road 41

Ningbo City, China

E-mail: liyujie24@gmail.com 
performed in addition to a D2 lymph node dissection. Among various adverse events, the most feared complication of this therapy is a leak from an injury site to the anterior surface of the pancreas with consequent development of a pancreatic fistula. Another concern is the possibility of the formation of bursectomy-related adhesions to the intestinal obstruction ${ }^{3}$.

Several factors may influence the effect of bursectomy including the location of the primary lesion, perioperative chemotherapy, and post-operative radiotherapy. Hirao et al. ${ }^{4}$ in a randomized controlled trial (RCT) found that the overall survival was similar in the bursectomy and non-bursectomy groups when the tumor was located in the upper one-third of the stomach. On the contrary, in tumors in the middle or lower third of the stomach, overall survival for the bursectomy group was significantly longer than that in the non-bursectomy group. This may be due to differences among the relapse patterns of tumors in the upper versus middle or lower third of the stomach. Moreover, adjuvant S-1 therapy after curative gastrectomy for advanced gastric cancer has been established, which implicates that chemotherapy can eliminate micrometastatic disease to a greater degree than surgical intervention. Up to now, few studies demonstrate the efficiency of radiotherapy after bursectomy.

To the best of our knowledge, only one meta-analysis $^{5}$ has compared the outcomes between bursectomy and non-bursectomy. However, this meta-analysis included a small number of studies and was published 3 years ago. In addition, the authors did not mention the patterns of recurrence, which were classified as peritoneal, hematogenous, and locoregional.

To elucidate the recurrence, safety, and survival benefits of bursectomy in gastric cancer surgery, we conducted a systematic review and meta-analysis of RCTs and non-randomized controlled trials (NRCTs).

\section{METHODS}

\section{Search strategy}

Using the Preferred Reporting Items for Systematic Reviews and Meta-Analyses guidelines, PubMed, Web of Knowledge, Medline, and Ovid's database were searched from January 2005 to July 2017 in the English language. The search terms used were "gastric cancer," "bursectomy," "complication," "recurrence," and "survival rate." The reference lists of relevant studies were checked manually to locate any missing studies.

\section{Study selection}

The full papers identified were assessed for eligibility for inclusion in the review by scanning the titles, abstracts, and keywords of every record retrieved. Clinical studies concerning comparisons of outcomes between a bursectomy group and a non-bursectomy group for gastric cancer were included regardless of whether they were RCTs or non-randomized controlled trials (NRCTs). Studies were restricted to those published in English.

\section{Data extraction}

Two coauthors (Yangjun Li and Yujie Li) independently selected studies for inclusion and exclusion and reached consensus when they did not agree in the initial assignment. The following variables were recorded: authors, journal and year of publication, number of patients, age, median tumor size, histological type, surgical procedure, complications, recurrence, and overall survival. If necessary, the corresponding authors of studies were contacted to obtain supplementary information. The Jadad et al. ${ }^{6}$ assessed the methodological quality of the eligible RCTs, and the methodological index assessed that of the NRCTs for non-randomized studies (MINORS) ${ }^{7}$.

\section{Quality assessment}

The Jadad scoring system was used for the randomized clinical trials (RCTs) ${ }^{6}$. The scale consists of three items, randomization, blinding, and description of the withdrawals and dropouts. Studies with a score of 3-5 were considered to be of high quality. Correspondingly, the Newcastle-Ottawa scale ${ }^{7}$ was used to assess the quality of non-randomized studies based on the following nine questions: (1) representativeness of the exposed cohort; (2) selection of the non-exposed cohort; (3) ascertainment of exposure; (4) demonstration that the outcome was not present at the outset of the study; (5) comparability; (6) assessment of outcome; (7) sufficient length of follow-up; (8) adequacy of participant follow-up; and (9) total number 
Figure 1 . Flowchart of the results of literature search.

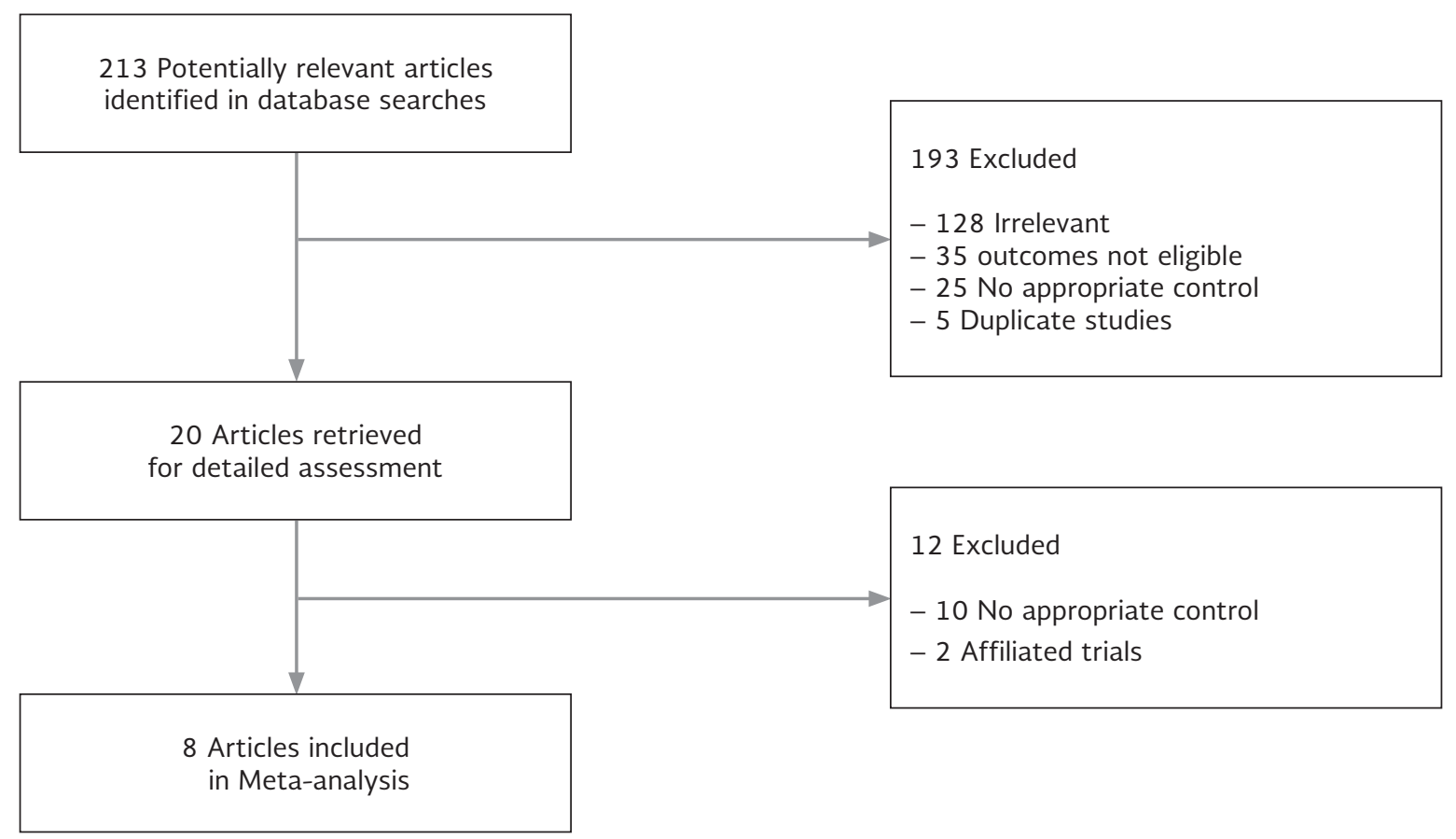

of "stars." Maximum score on this scale is a total of 9. "Good" was defined as a total score of 7-9; "fair," a total score of 4-6; and "poor," a total score of $<4$.

\section{Statistical analysis}

A formal meta-analysis was carried out for all included studies comparing the results from the bursectomy group with the non-bursectomy group for gastric cancer. The outcomes in our study were complications, recurrence, and overall survival. A fixed effects model was used to calculate a pooled odds ratio (OR) with its 95\% confidence interval $(\mathrm{Cl})$. Heterogeneity was explored using $\mathrm{I}^{2}$ statistics, a measure of how much the variance between studies, rather than chance, can be attributed to inter study differences. $12>50 \%$ was regarded to indicate strong heterogeneity. The Cochrane Collaboration's Review Manager Software (Revman version 5.0) was utilized for the data analysis.

\section{RESULTS}

\section{Study selection}

A total of 213 potentially relevant titles and abstracts were obtained (Fig. 1). After exclusion of duplicate references, non-relevant literature, and those that did not satisfy the inclusion criteria, 20 candidate articles were considered for the meta-analysis. After careful review of the full text of these articles, eight studies fulfilled the eligibility criteria. The reports by Fujita et al., Hirao et al., and Imamura et al., which provide different results of RCTs from the same institute, were regarded as one study. Other five papers were retrospective clinical trials. Details of the included studies are summarized in tables 1 and 2 .

The publication dates ranged from January 2010 to July 2017. Study sizes ranged from 108 to 470 patients.

\section{Outcome measures}

A total of 644 patients who underwent bursectomy and 1000 patients who did not undergo bursectomy were analyzed. The total post-operative complications were $23.9 \%$ for patients with bursectomy and $23.6 \%$ for non-bursectomy patients according to the six included studies; the non-bursectomy group had fewer complications, but no significant difference was found (OR $=1.06,95 \%$ $\mathrm{Cl}$ [0.83-1.35], $p=0.63$ ) (Fig. 2). The overall prevalence of recurrence was $24.60 \%$ in the bursectomy 
Table 1. Summary and comparison of baseline characteristics between bursectomy and non-bursectomy patients.

\begin{tabular}{|c|c|c|c|c|c|c|c|c|c|}
\hline \multirow[t]{2}{*}{ Author, Year } & \multirow[t]{2}{*}{ Country } & \multirow{2}{*}{$\begin{array}{l}\text { Study } \\
\text { design }\end{array}$} & \multirow{2}{*}{$\begin{array}{c}\text { Number } \\
\text { of } \\
\text { patients }\end{array}$} & \multirow{2}{*}{$\begin{array}{l}\text { Sex (male/ } \\
\text { female) }\end{array}$} & \multirow{2}{*}{$\begin{array}{l}\text { Mean } \\
\text { age }\end{array}$} & \multicolumn{2}{|c|}{ Tumor location } & \multirow{2}{*}{$\begin{array}{c}\text { Median } \\
\text { tumor size } \\
(\mathrm{cm})\end{array}$} & \multirow{2}{*}{$\begin{array}{l}\text { Quality } \\
\text { score }^{a}\end{array}$} \\
\hline & & & & & & $\mathrm{U}$ & $M+L$ & & \\
\hline $\begin{array}{l}\text { Hasegawa } \\
\text { et al., } 2012^{8}\end{array}$ & Japan & NRCT & 196 & $\begin{array}{l}\text { BS: } 72 / 26 \\
\text { NBS: } 72 / 26\end{array}$ & $\begin{array}{c}\text { BS: } 69 \\
\text { NBS: } 68.7\end{array}$ & - & - & - & $7 / 9$ \\
\hline $\begin{array}{l}\text { Fujita et al., } \\
2012^{9}\end{array}$ & Japan & $\mathrm{RCT}$ & 210 & $\begin{array}{l}\text { BS: } 73 / 31 \\
\text { NBS: } 77 / 29\end{array}$ & $\begin{array}{l}\text { BS: } 65 \\
\text { NBS: } 63\end{array}$ & $\begin{array}{l}\text { BS: } 15 \\
\text { NBS: } 16\end{array}$ & $\begin{array}{l}\text { BS: } 89 \\
\text { NBS: } 90\end{array}$ & $\begin{array}{l}\text { BS: } 4.3 \\
\text { NBS: } 4.5\end{array}$ & $3 / 5$ \\
\hline $\begin{array}{l}\text { Imamura et al., } \\
2010^{10}\end{array}$ & Japan & $\mathrm{RCT}$ & 210 & $\begin{array}{l}\text { BS: } 73 / 31 \\
\text { NBS: } 77 / 29\end{array}$ & $\begin{array}{l}\text { BS: } 65 \\
\text { NBS: } 63\end{array}$ & $\begin{array}{l}\text { BS: } 15 \\
\text { NBS: } 16\end{array}$ & $\begin{array}{l}\text { BS: } 89 \\
\text { NBS: } 90\end{array}$ & $\begin{array}{l}\text { BS: } 4.3 \\
\text { NBS: } 4.5\end{array}$ & $3 / 5$ \\
\hline $\begin{array}{l}\text { Hirao et al., } \\
2015^{4}\end{array}$ & Japan & $\mathrm{RCT}$ & 210 & $\begin{array}{l}\text { BS: } 73 / 31 \\
\text { NBS: } 77 / 29\end{array}$ & $\begin{array}{l}\text { BS: } 65 \\
\text { NBS: } 63\end{array}$ & $\begin{array}{l}\text { BS: } 15 \\
\text { NBS: } 16\end{array}$ & $\begin{array}{l}\text { BS: } 89 \\
\text { NBS: } 90\end{array}$ & $\begin{array}{l}\text { BS: } 4.3 \\
\text { NBS: } 4.5\end{array}$ & $3 / 5$ \\
\hline $\begin{array}{l}\text { Kochi et al., } \\
2014^{11}\end{array}$ & Japan & NRCT & 254 & $\begin{array}{c}\text { BS: } 82 / 39 \\
\text { NBS: } 97 / 36\end{array}$ & $\begin{array}{l}\text { BS: } 67 \\
\text { NBS: } 66\end{array}$ & $\begin{array}{l}\text { BS: } 25 \\
\text { NBS: } 24\end{array}$ & $\begin{array}{c}\text { BS: } 96 \\
\text { NBS: } 109\end{array}$ & $\begin{array}{l}\text { BS: } 3.5 \\
\text { NBS: } 3.5\end{array}$ & $7 / 9$ \\
\hline $\begin{array}{l}\text { Zhang et al., } \\
2014^{12}\end{array}$ & China & NRCT & 406 & $\begin{array}{l}\text { BS: } 108 / 51 \\
\text { NBS: } 160 / 87\end{array}$ & $\begin{array}{l}\text { BS: } 57.3 \\
\text { NBS: } 58.3\end{array}$ & $\begin{array}{l}\text { BS: } 62 \\
\text { NBS: } 28\end{array}$ & $\begin{array}{c}\text { BS: } 97 \\
\text { NBS: } 219\end{array}$ & $\begin{array}{l}\text { BS: } 5.6 \\
\text { NBS: } 5.7\end{array}$ & $6 / 9$ \\
\hline $\begin{array}{l}\text { Shchepotin } \\
\text { et al., } 2013^{13}\end{array}$ & Ukraine & NRCT & 108 & - & - & - & - & - & $5 / 9$ \\
\hline $\begin{array}{l}\text { Eom et al., } \\
2013^{22}\end{array}$ & Korea & NRCT & 470 & $\begin{array}{c}\text { BS: } 65 / 42 \\
\text { NBS: } 241 / 122\end{array}$ & $\begin{array}{l}\text { BS: } 56.1 \\
\text { NBS: } 57.1\end{array}$ & $\begin{array}{l}\text { BS: } 13 \\
\text { NBS: } 62\end{array}$ & $\begin{array}{l}\text { BS: } 66 \\
\text { NBS: } 242\end{array}$ & $\begin{array}{l}\text { BS: } 6.7 \\
\text { NBS: } 6.0\end{array}$ & $7 / 9$ \\
\hline
\end{tabular}

ajadad score for RCTs, NOS score for NRCTs.

U: upper, M: middle, L: lower, BS: bursectomy, NBS: non-bursectomy. RCT: randomized controlled trial.

Figure 2. Meta-analysis of total complications for bursectomy group versus non-bursectomy group.

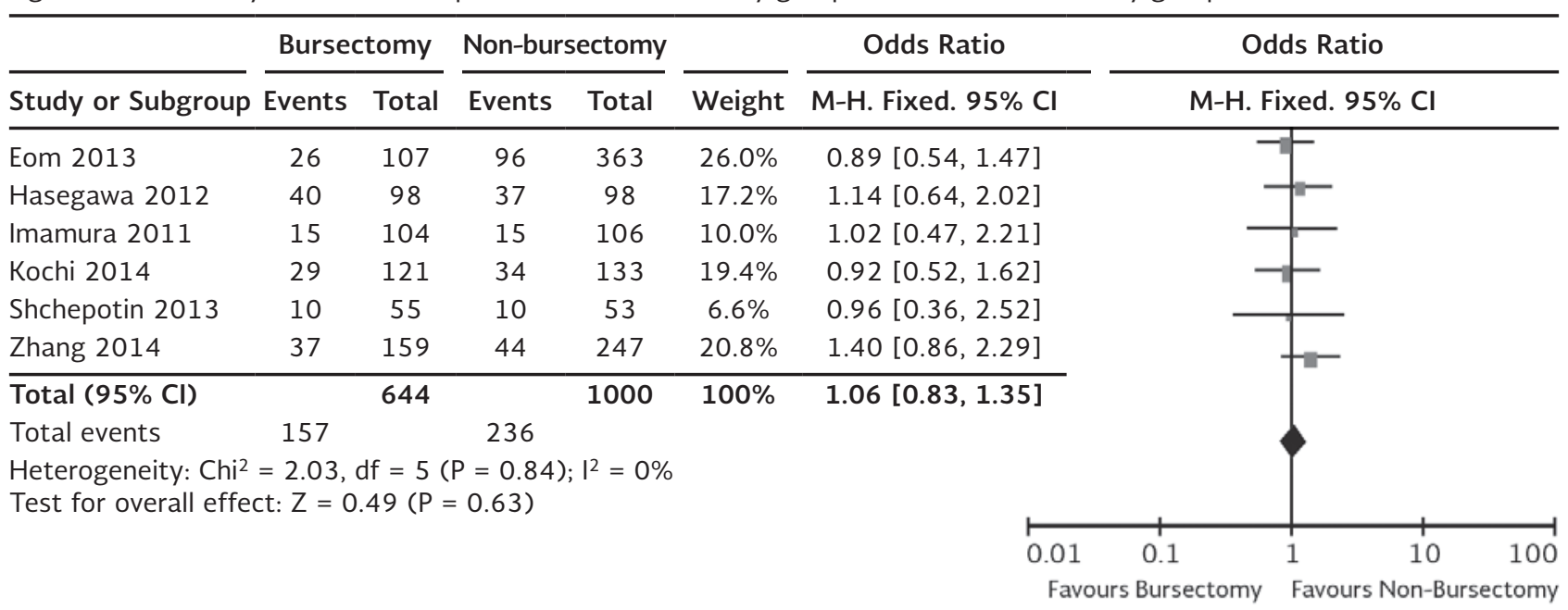

group versus $25.04 \%$ in the non-bursectomy group, without significant difference $(O R=1.07,95 \%$ $\mathrm{Cl}$ [0.77-1.50], $p=0.68$ ). In the bursectomy group, each pattern of recurrence had similar proportions (range 4.21-7.77\%); the same occurred for the non-bursectomy group (5.64-8.11\%) (Fig. 3). Comparing the proportion of each pattern between the two groups, there were no significant differences ( $p=0.96,0.95$, and 0.52 , respectively). The prevalence of 3-year overall survival was $86.07 \%$ in the bursectomy group versus $89.02 \%$ in the nonbursectomy group, and this difference was not significant $(\mathrm{OR}=1.30,95 \% \mathrm{Cl}[0.82-2.07], p=0.26)$ (Fig. 4). The prevalence of 5 -year overall survival was $73.54 \%$ in the bursectomy group versus $72.31 \%$ in the non-bursectomy group, and no significant difference was observed (OR $=0.91,95 \%$ $\mathrm{Cl}$ [0.66-1.27], $\mathrm{p}=0.58$ ) (Fig. 5). 
Table 2. Summary and comparison of baseline characteristics between bursectomy and non-bursectomy patients.

\begin{tabular}{|c|c|c|c|c|c|c|c|}
\hline Author, Year & $\begin{array}{l}\text { Histological type } \\
\text { (differentiated/ } \\
\text { undifferentiated) }\end{array}$ & $\begin{array}{l}\text { p-stage } \\
\text { (Stage I II/ } \\
\text { Stage III IV) }\end{array}$ & $\begin{array}{c}\text { pT stage } \\
\text { (T1 T2/ } \\
\text { T3 T4) }\end{array}$ & $\begin{array}{l}\text { pN stage } \\
(\mathrm{N} 0 \sim \mathrm{N} 1 / \\
\mathrm{N} 2 \sim \mathrm{N} 3)\end{array}$ & $\begin{array}{l}\text { Surgical } \\
\text { procedure } \\
\text { (TG/DG) }\end{array}$ & $\begin{array}{c}\text { Adjuvant } \\
\text { chemotherapy }\end{array}$ & $\begin{array}{l}\text { Follow-up } \\
\text { (months) }\end{array}$ \\
\hline $\begin{array}{l}\text { Hasegawa et al., } \\
2012^{8}\end{array}$ & $\begin{array}{l}\text { BS: } 61 / 37 \\
\text { NBS: } 58 / 40\end{array}$ & $\begin{array}{l}\text { BS: } 56 / 42 \\
\text { NBS: } 57 / 41\end{array}$ & $\begin{array}{l}\text { BS: } 43 / 137 \\
\text { NBS: } 55 / 95\end{array}$ & $\begin{array}{l}\text { BS: } 64 / 34 \\
\text { NBS: } 64 / 34\end{array}$ & $\begin{array}{l}\text { BS: } 46 / 52 \\
\text { NBS: } 37 / 63\end{array}$ & $\begin{array}{l}\text { BS:20 } \\
\text { NBS: } 34\end{array}$ & 108 \\
\hline $\begin{array}{l}\text { Fujita et al., } \\
2012^{9}\end{array}$ & - & - & $\begin{array}{l}\text { BS: } 79 / 25 \\
\text { NBS: } 83 / 23\end{array}$ & $\begin{array}{l}\text { BS: } 86 / 18 \\
\text { NBS: } 84 / 22\end{array}$ & - & - & 54 \\
\hline $\begin{array}{l}\text { Imamura et al., } \\
2010^{10}\end{array}$ & $\begin{array}{l}\text { BS: } 47 / 57 \\
\text { NBS: } 50 / 56\end{array}$ & - & $\begin{array}{l}\text { BS: } 79 / 25 \\
\text { NBS: } 83 / 23\end{array}$ & $\begin{array}{c}\text { BS: } 86 / 18 \\
\text { NBS: } 84 / 22\end{array}$ & - & - & 54 \\
\hline $\begin{array}{l}\text { Hirao et al., } \\
2015^{4}\end{array}$ & $\begin{array}{c}\text { BS: } 47 / 57 \\
\text { NBS: } 50 / 56\end{array}$ & - & $\begin{array}{l}\text { BS: } 79 / 25 \\
\text { NBS: } 83 / 23\end{array}$ & $\begin{array}{l}\text { BS: } 86 / 18 \\
\text { NBS: } 84 / 22\end{array}$ & - & - & 54 \\
\hline $\begin{array}{l}\text { Kochi et al., } \\
2014^{11}\end{array}$ & $\begin{array}{c}\text { BS:63/58 } \\
\text { NBS: } 64 / 69\end{array}$ & - & - & - & $\begin{array}{l}\text { BS: } 36 / 85 \\
\text { NBS: } 36 / 97\end{array}$ & - & 68 \\
\hline $\begin{array}{l}\text { Zhang et al., } \\
2014^{12}\end{array}$ & - & $\begin{array}{l}\text { BS: } 54 / 105 \\
\text { NBS: } 86 / 161\end{array}$ & $\begin{array}{c}\text { BS:20/139 } \\
\text { NBS:48/199 }\end{array}$ & $\begin{array}{c}\text { BS:63/96 } \\
\text { NBS: } 111 / 136\end{array}$ & $\begin{array}{c}\text { BS: } 86 / 73 \\
\text { NBS: } 63 / 184\end{array}$ & - & 24 \\
\hline $\begin{array}{l}\text { Shchepotin et al., } \\
2013^{13}\end{array}$ & - & - & - & - & - & - & - \\
\hline $\begin{array}{l}\text { Eom et al., } \\
2013^{22}\end{array}$ & $\begin{array}{c}\text { BS: } 38 / 69 \\
\text { NBS: } 137 / 226\end{array}$ & $\begin{array}{c}\text { BS: } 33 / 73 \\
\text { NBS: } 202 / 155\end{array}$ & $\begin{array}{c}\text { BS: } 10 / 97 \\
\text { NBS: } 79 / 284\end{array}$ & $\begin{array}{c}\text { BS: } 59 / 48 \\
\text { NBS: } 235 / 128\end{array}$ & $\begin{array}{c}\text { BS: } 43 / 64 \\
\text { NBS: } 147 / 216\end{array}$ & $\begin{array}{c}\text { BS: } 68 \\
\text { NBS: } 238\end{array}$ & 66 \\
\hline
\end{tabular}

TG: total gastrectomy, DG: distal gastrectomy, BS: bursectomy, NBS: non-bursectomy.

\section{DISCUSSION}

Several studies have led to radical gastrectomy with extended D2 removal of regional lymph nodes becoming the standard treatment for curable gastric cancer ${ }^{14-16}$. The effect of bursectomy on overall survival of patients with gastric cancer remains unclear. Considering the balance between the risk and benefit of each surgical procedure, some researchers have remained skeptical about prophylactic bursectomy. Two factors are necessary for bursectomy to be accepted as a standard treatment for advanced gastric cancer: safety and oncologic benefit. In the current study, we compared the total complications, recurrence, and long-term survival of patients with gastric cancer between the bursectomy and non-bursectomy groups.

Removing the mesocolon and pancreatic capsule is physically detrimental to patients and increases the risk of intraoperative and/or post-operative complications. A previous study reported that subclinical pancreatic fistula could occur in up to $10 \%$ of the patients with the resection of the pancreatic capsule $^{17}$. However, other studies ${ }^{9-11}$ indicated that the incidence of major post-operative complications including pancreatic fistula, anastomotic leakage, abdominal abscess, bowel obstruction, and hemorrhage was not significant difference between the two groups. They also pointed out that pancreatic fistula may not be caused by the removal of the pancreatic capsule but by the lymph node dissection adjacent to the pancreas parenchyma. As the safety of surgical treatments strongly depends on the surgeon's experience, the literature suggests that bursectomy can safely be performed by experienced surgeons ${ }^{9}$. For our research, gastrectomy with bursectomy does not increase the risk of post-operative complications.

Locoregional recurrences in gastric cancer have been reported to be as high as $72 \%{ }^{18}$. Radical resection of the bursa omentalis for gastric cancer, which may eliminate the majority of cancer cells seeded within the peritoneum ${ }^{19}$, has been advised for almost a century ${ }^{1}$ as one of the strategies to reduce locoregional recurrence. Hasegawa et al. ${ }^{8}$ indicated that complete omentectomy and extensive lymph node resection during gastrectomy improved the survival of patients with peritoneal metastasis of gastric cancer. Nevertheless, our meta-analysis did not show any benefit on each pattern of recurrence. As Yamamura et al. 
Figure 3. Meta-analysis of recurrences for bursectomy group versus non-bursectomy group.

\begin{tabular}{|c|c|c|c|c|c|c|}
\hline \multirow[b]{2}{*}{ Study or Subgroup } & \multicolumn{2}{|c|}{ Bursectomy } & \multicolumn{2}{|c|}{ Non-bursectomy } & \multirow[b]{2}{*}{ Weight } & \multirow{2}{*}{$\frac{\text { Odds Ratio }}{\text { M-H. Fixed. } 95 \% \mathrm{Cl}}$} \\
\hline & Events & Total & Events & Total & & \\
\hline \multicolumn{7}{|c|}{ 2.1.1 Peritoneal recurrence } \\
\hline Eom 2013 & 7 & 107 & 18 & 363 & $23.2 \%$ & $1.34[0.54,3.30]$ \\
\hline Fujita 2012 & 9 & 104 & 14 & 106 & $38.3 \%$ & $0.62[0.26,1.51]$ \\
\hline Hasegawa 2012 & 7 & 98 & 7 & 98 & $19.7 \%$ & $1.00[0.34,2.97]$ \\
\hline Kochi 2014 & 8 & 121 & 7 & 133 & $18.8 \%$ & $1.27[0.45,3.63]$ \\
\hline gure & & 430 & & 700 & $100 \%$ & $0.99[0.61,1.60]$ \\
\hline Total events & 31 & & 46 & & & \\
\hline
\end{tabular}

Heterogeneity: $\mathrm{Chi}^{2}=1.72, \mathrm{df}=3(\mathrm{P}=0.63) ; \mathrm{I}^{2}=0 \%$

Test for overall effect: $Z=0.06(P=0.96)$

2.1.2 Hematogenous recurrence

\begin{tabular}{lcccccc} 
Eom 2013 & 12 & 107 & 29 & 363 & $42.6 \%$ & $1.45[0.72,2.96]$ \\
Fujita 2012 & 4 & 104 & 6 & 106 & $20.7 \%$ & $0.67[0.18,2.43]$ \\
Hasegawa 2012 & 8 & 98 & 11 & 98 & $36.7 \%$ & $0.70[0.27,1.83]$ \\
\hline Subtotal $(95 \% \mathrm{Cl})$ & & 309 & & 567 & $100 \%$ & $1.02[0.60,1.72]$ \\
Total events & 24 & & 46 & & &
\end{tabular}

Heterogeneity: $\mathrm{Chi}^{2}=1.96, \mathrm{df}=2(\mathrm{P}=0.38) ; \mathrm{I}^{2}=0 \%$

Test for overall effect: $Z=0.06(P=0.95)$

\subsubsection{Locoregional recurrence}

\begin{tabular}{lcccccc} 
Eom 2013 & 3 & 107 & 25 & 363 & $62.8 \%$ & $0.39[0.12,1.32]$ \\
Fujita 2012 & 7 & 104 & 5 & 106 & $26.2 \%$ & $1.46[0.45,4.75]$ \\
Hasegawa 2012 & 3 & 98 & 2 & 98 & $11.0 \%$ & $1.52[0.25,9.28]$ \\
\hline Subtotal $(95 \% \mathrm{Cl})$ & & 309 & & 567 & $100 \%$ & $0.79[0.39,1.62]$ \\
Total events & 13 & & 32 & & &
\end{tabular}

Heterogeneity: $\mathrm{Chi}^{2}=2.82, \mathrm{df}=2(\mathrm{P}=0.24) ; \mathrm{I}^{2}=29 \%$

Test for overall effect: $Z=0.64(P=0.52)$

2.1.4 Overall recurrence

\begin{tabular}{lcccccc} 
Eom 2013 & 34 & 107 & 95 & 363 & $44.4 \%$ & $1.31[0.82,2.10]$ \\
Fujita 2012 & 24 & 104 & 27 & 106 & $31.0 \%$ & $0.88[0.47,1.65]$ \\
Hasegawa 2012 & 18 & 98 & 20 & 98 & $24.6 \%$ & $0.88[0.43,1.78]$ \\
\hline Subtotal $(95 \% \mathrm{Cl})$ & & 309 & & 567 & $100 \%$ & $1.07[0.77,1.50]$ \\
Total events & 76 & & 142 & & &
\end{tabular}

Heterogeneity: $\mathrm{Chi}^{2}=1.41, \mathrm{df}=2(\mathrm{P}=0.49) ; \mathrm{I}^{2}=0 \%$

Test for overall effect: $Z=0.41(P=0.68)$

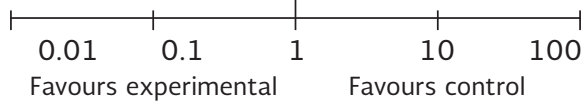

pointed out, it is improbable that viable cancer cells disseminated into the bursa remain restricted to this cavity without migrating into the free abdominal cavity $^{20}$. Routine bursectomy may not be an essential procedure for resecting gastric cancer, from the viewpoint of eliminating microscopic peritoneal deposits within the omental bursa.

There are little data to support bursectomy in improving the overall survival rates of patients. Only 
Figure 4. Meta-analysis of 3-year overall survival for bursectomy group versus non-bursectomy group.

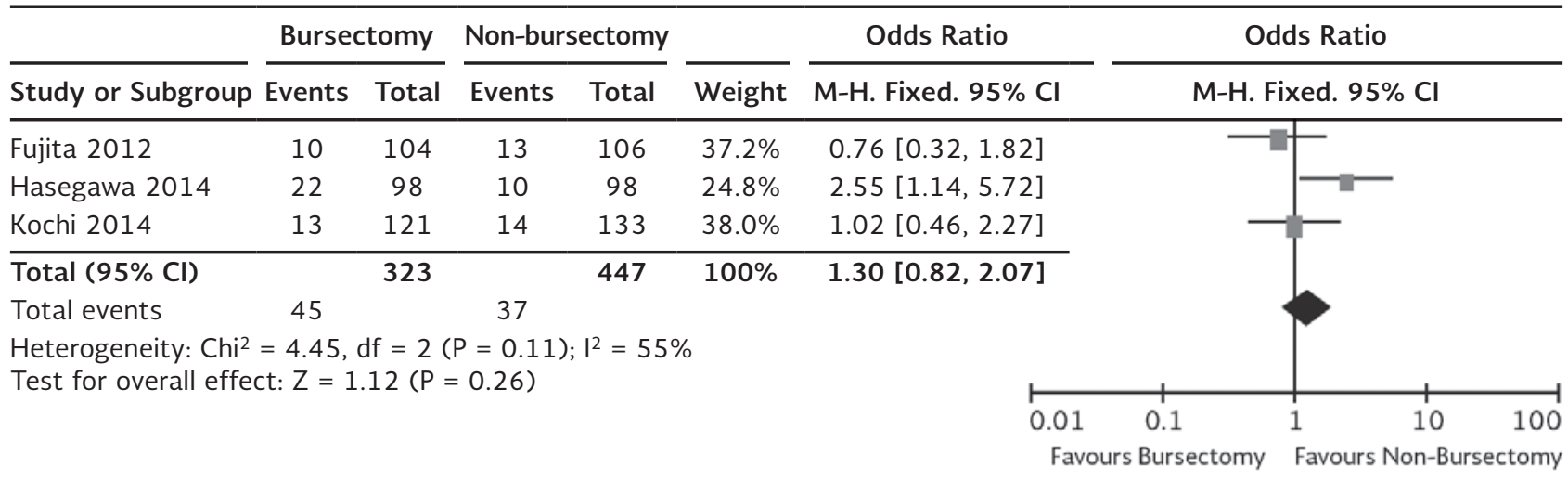

Figure 5. Meta-analysis of 5-year overall survival for bursectomy group versus non-bursectomy group.

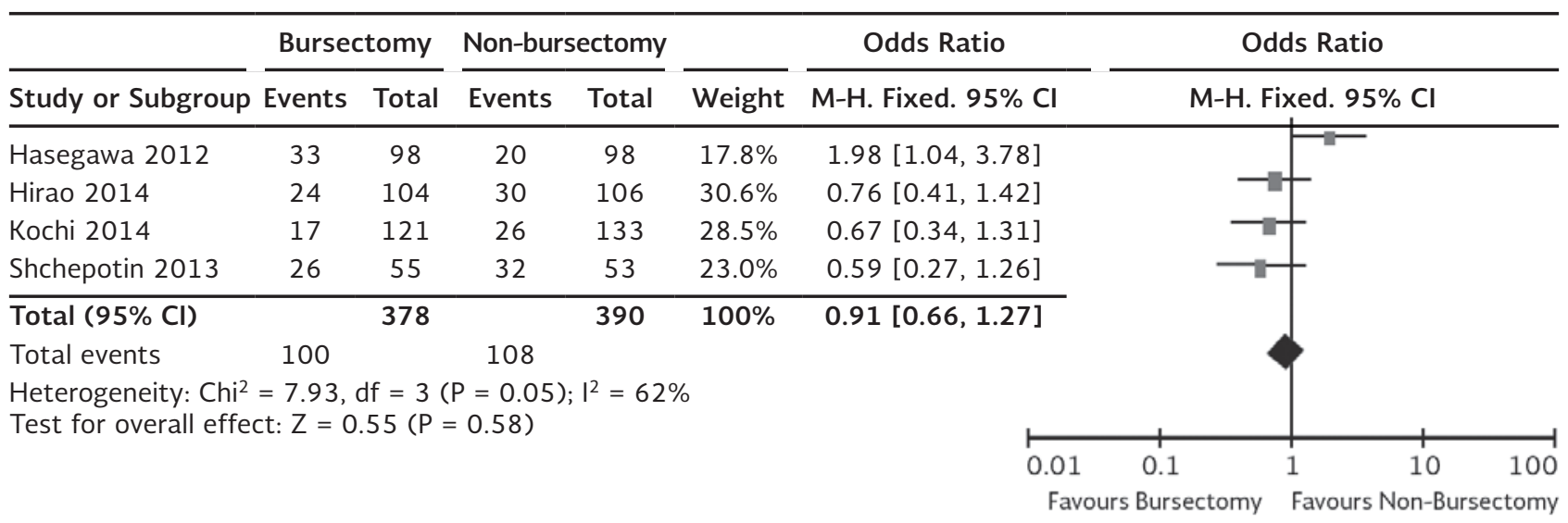

Shchepotin et al. ${ }^{13}$ pointed out that bursectomy was associated with a better 5-year survival. Other retrospective studies failed to show any survival advantage of bursectomy ${ }^{8,11,21}$. In a randomized controlled study, bursectomy was not an important prognostic factor in the multivariate analysis ${ }^{10}$. Although they demonstrated a potential effect of bursectomy on survival among the patients with serosa-positive gastric cancer, it was too weak to reach a clear conclusion. Two included studies 8,22 mentioned the use of perioperative chemotherapy; however, they did not explain the effect of chemotherapy on patients.

The lack of survival benefit of bursectomy in our study may be explained by several factors. First, the cavity of the bursa omentalis is not a closed space, but remains open to the abdominal cavity, as suggested by Yamamura et al. ${ }^{20}$ In this work, carcinoembryonic antigen or cytokeratin 20 mRNA was detected not only in the bursa omentalis but also in other parts of the abdominal cavity in most cases. Hence, all disseminated free cancer cells cannot be eliminated by bursectomy. Second, it is possible that bursectomy was not performed completely in most cases on account of a highly technical experience required. Especially, fat amount and fat density of the omentum are principal factors of surgical quality. Completeness of the bursectomy may be different based on the number and nature of the patient's mesenteric fat and degree of bleeding tendency.

There are some limitations in our study. First, most of the included studies were retrospective chart reviews with inherent limitations such as selection bias and inaccurate or missing data reports. Second, our analysis included only studies published in English. Finally, the sample size of the included studies was too small to exclude beta error. Hence, our findings must be interpreted with caution. 


\section{REFERENCES}

1. Hagiwara A, Sawai K, Sakakura C, et al. Complete omentectomy and extensive lymphadenectomy with gastrectomy improves the survival of gastric cancer patients with metastases in the adjacent peritoneum. Hepatogastroenterology. 1998;45:1922-9.

2. Japanese Gastric Cancer Association. Japanese gastric cancer treatment guidelines 2010 (ver. 3). Gastric Cancer. 2011;14: 113-23.

3. Kayaalp C, Piskin T, Olmez A. Complications of bursectomy after radical gastrectomy for gastric cancer. World J Surg. 2012; $36: 229$.

4. Hirao M, Kurokawa Y, Fujita J, et al. Long-term outcomes after prophylactic bursectomy in patients with resectable gastric cancer: final analysis of a multicenter randomized controlled trial. Surgery. 2015;157:1099-105.

5. Shen WS, Xi HQ, Wei B, Chen L. Effect of gastrectomy with bursectomy on prognosis of gastric cancer: a meta-analysis. World J Gastroenterol. 2014;20:14986-91.

6. Jadad AR, Moore RA, Carroll D, et al. Assessing the quality of reports of randomized clinical trials: is blinding necessary? Control Clin Trials. 1996;17:1-12.

7. Stang A. Critical evaluation of the Newcastle-Ottawa scale for the assessment of the quality of nonrandomized studies in meta-analysis. Eur J Epidemiol. 2010;25:603-5.

8. Hasegawa $\mathrm{S}$, Kunisaki $\mathrm{C}$, Ono $\mathrm{H}$, et al. Omentum-preserving gastrectomy for advanced gastric cancer: a propensity-matched retrospective cohort study. Gastric Cancer. 2013;16:383-8.

9. Fujita J, Kurokawa $Y$, Sugimoto T, et al. Survival benefit of bursectomy in patients with resectable gastric cancer: interim analysis results of a randomized controlled trial. Gastric Cancer. 2012;15:42-8

10. Imamura H, Kurokawa $\mathrm{Y}$, Kawada J, et al. Influence of bursectomy on operative morbidity and mortality after radical gastrectomy for gastric cancer: results of a randomized controlled trial. World J Surg. 2011;35:625-30.

11. Kochi M, Fujii M, Kanamori N, et al. D2 gastrectomy with versus without bursectomy for gastric cancer. Am J Clin Oncol. 2014; $37: 222-6$
12. Zhang $W H$, Chen $X Z$, Yang $K$, et al. Bursectomy and non-bursectomy D2 gastrectomy for advanced gastric cancer, initial experience from a single institution in China. World J Surg Oncol. 2015;13:332.

13. Shchepotin I, Kolesnik O, Lukashenko A, Rozumiy D, Burlaka A. D2 gastrectomy with versus without bursectomy for gastric cancer: result of single center randomized trial. Ann Oncol. 2013;24: iv65

14. Sasako M, McCulloch P, Kinoshita T, Maruyama K. New method to evaluate the therapeutic value of lymph node dissection for gastric cancer. Br J Surg. 1995;82:346-51.

15. Ziqiang W, Feng Q, Zhimin C, et al. Comparison of laparoscopically assisted and open radical distal gastrectomy with extended lymphadenectomy for gastric cancer management. Surg Endosc. 2006;20:1738-43.

16. de Aretxabala $X$, Konishi $K$, Yonemura $Y$, et al. Node dissection in gastric cancer. Br J Surg. 1987;74:770-3.

17. Herbella FA, Tineli AC, Wilson JL Jr, Del Grande JC. Gastrectomy and lymphadenectomy for gastric cancer: is the pancreas safe? J Gastrointest Surg. 2008;12:1912-14.

18. Macdonald JS, Smalley SR, Benedetti ], et al Chemoradiotherapy after surgery compared with surgery alone for adenocarcinoma of the stomach or gastroesophageal junction. $N$ Engl J Med. 2001;345:725-30.

19. Hagiwara A, Takahashi T, Sawai K, et al. Milky spots as the implantation site for malignant cells in peritoneal dissemination in mice. Cancer Res. 1993;53:687-92.

20. Yamamura $Y$, Ito $S$, Mochizuki $Y$, Nakanishi $H$, Tatematsu $M$ Kodera Y. Distribution of free cancer cells in the abdominal cavity suggests limitations of bursectomy as an essential component of radical surgery for gastric carcinoma. Gastric Cancer. 2007;10:24-8.

21. Yoshikawa T, Tsuburaya A, Kobayashi, et al. Is bursectomy necessary for patients with gastric cancer invading the serosa? Hepatogastroenterology. 2004;51:1524-6.

22. Eom BW, Joo J, Kim YW, et al. Role of bursectomy for advanced gastric cancer: result of a case-control study from a large volume hospital. Eur J Surg Oncol. 2013;39:1407-14. 